\title{
Synthesis and some stereoselective radical additions of bis[(phenyldimethylsilyl)methyl]tin dihydride
}

\author{
M. Belén Faraoni, ${ }^{a}$ Verónica I. Dodero, ${ }^{a}$ and Julio C. Podestá ${ }^{\text {a,b* }}$ \\ ${ }^{a}$ Instituto de Investigaciones en Quimica Organica, Departamento de Quimica, Universidad \\ Nacional del Sur, Avda. Alem 1253, 8000 Bahia Blanca, Argentina. ${ }^{b}$ Consejo Nacional de \\ Investigaciones Cientificas y Tecnicas (CONICET), Buenos Aires, Argentina \\ E-mail:jpodesta@criba.edu.ar
}

Dedicated to Professor Rosa Lederkremer on her $70^{\text {th }}$ birthday

\begin{abstract}
The synthesis of the new bis[(phenyldimethylsilyl)methyl]tin dihydride (6) starting from chloromethyldimethylsilicon chloride is reported. A study on the radical additions of $\mathbf{6}$ to various mono- and disubstituted alkynes shows that these reactions take place with high and in some cases with complete stereoselectivity. Full ${ }^{1} \mathrm{H}-,{ }^{13} \mathrm{C}$-, and ${ }^{119} \mathrm{Sn}-\mathrm{NMR}$ data of the new organtins are given.
\end{abstract}

Keywords: Bis[(phenyldimethylsilyl)methyl]tin dihydride, stereoselective radical additions, divinyltins

\section{Introduction}

Organotin hydrides have found many applications in organic synthesis not only as reducing reagents but also as intermediates in the generation of carbon-carbon bonds, and for the preparation of compounds such as vinylstannanes, which are invaluable starting materials for cross-coupling reactions. ${ }^{1}$ In previous studies we have shown that the size of the organic ligands attached to the tin atom affects not only the reactivity but also the stereoselectivity of the reactions of these compounds. ${ }^{2}$ We have also recently reported the synthesis of tin compounds containing the ligand (phenyldimethylsilyl)methyl like tris[(phenyldimethylsilyl)methyl]tin hydride. ${ }^{3}$ Taking into account these facts, and following our investigations on the relationship between the steric volume of the substituents attached to the tin atom and the reactivity as well as the stereoselectivity of organotin hydrides, we considered it to be of interest to carry out the synthesis of bis[(phenyldimethylsilyl)methyl]tin dihydride (6) and to study some reactions of this new bulky tin hydride. 


\section{Results and Discussion}

The total synthesis of bis[(phenyldimethylsilyl)methyl]tin dihydride (6) was carried out according to Scheme 1.
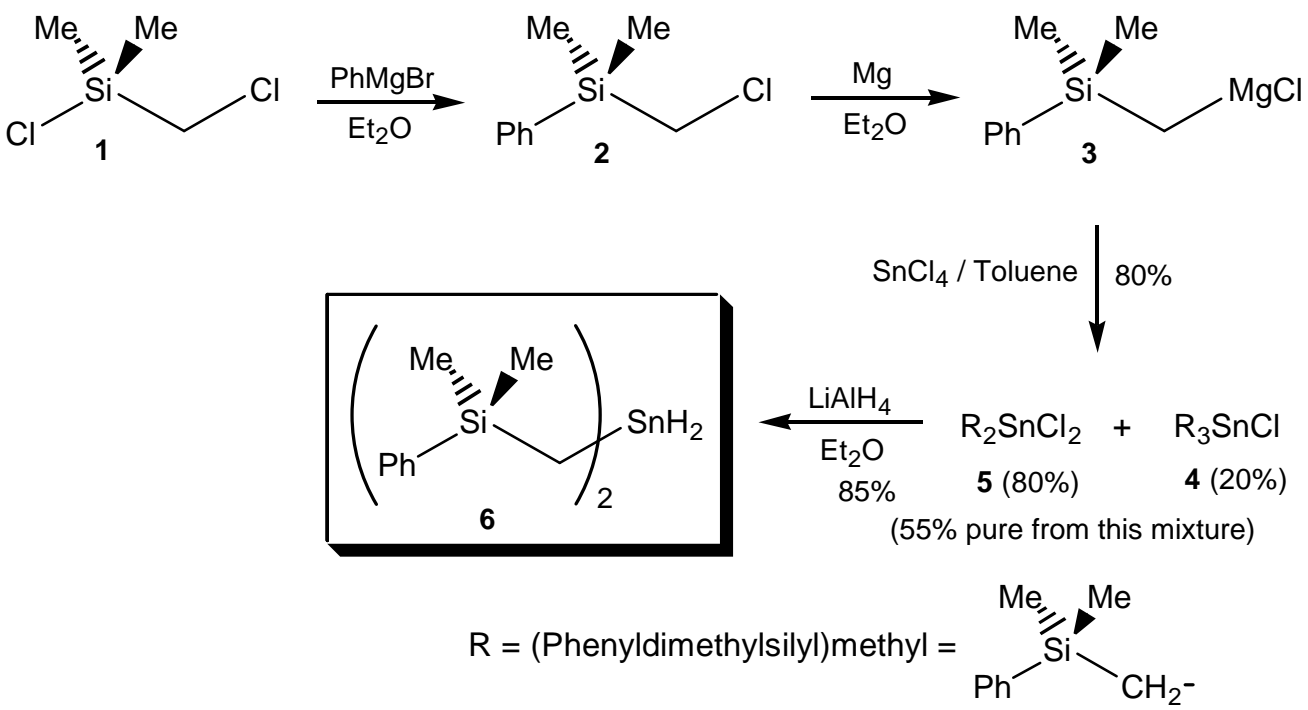

\section{Scheme 1}

The alkylation of tin tetrachloride with (phenyldimethylsilyl)methylmagnesium chloride (3) using a ratio Grignard reagent/ $\mathrm{SnCl}_{4}=2.1$ was repeated eight times, always obtaining a mixture of chlorides 4 and 5 in almost equal proportions, with an average yield of about $80 \%$. These mixtures were very soluble in methylene chloride, diethyl ether, hexane, and petroleum ether, even at low temperatures $\left(0\right.$ to $\left.-23^{\circ} \mathrm{C}\right)$, and we were unable to recrystallize 5 pure from these mixtures. Taking into account these results, we decided to carry out a study of the reaction under different experimental conditions and $3 / \mathrm{SnCl}_{4}$ ratios. In all the experiments the Grignard reagent was added dropwise to the solution of tin tetrachloride in toluene. The results obtained are summarized in Table 1. From the mixture obtained in entry 7 (Table 1), an average of ten experiments, we were able to obtain dichloride 5 pure in an average yield of $55 \%$ by crystallization from heptane. It should be noted that we have previously obtained 5 but in very low yield. ${ }^{3}$ The reduction of $\mathbf{5}$ with lithium aluminum hydride gave the desired bis[(phenyldimethylsilyl)methyl]tin dihydride (6) in $85 \%$ yield

To test whether it was possible to perform stereoselective hydrostannations under radical conditions using dihydride 6, we carried out the addition of this hydride to phenylethyne (a), 2naphthylethyne (b), methyl propiolate (c), diphenylethyne (d), and methyl 3-phenylpropiolate (e). Taking into account previous works, ${ }^{2 f,} 4$ we considered it possible that under these conditions the main products of the hydrostannations should be those corresponding to an anti addition of the hydride to the carbon-carbon triple bond. Thus, the anti addition of tin dihydride 6 to these alkynes could lead to the three possible regioisomers A-1/A-3 shown in Scheme 2. 
A summary of the obtained results as well as the best reaction conditions is shown in Table 2 .
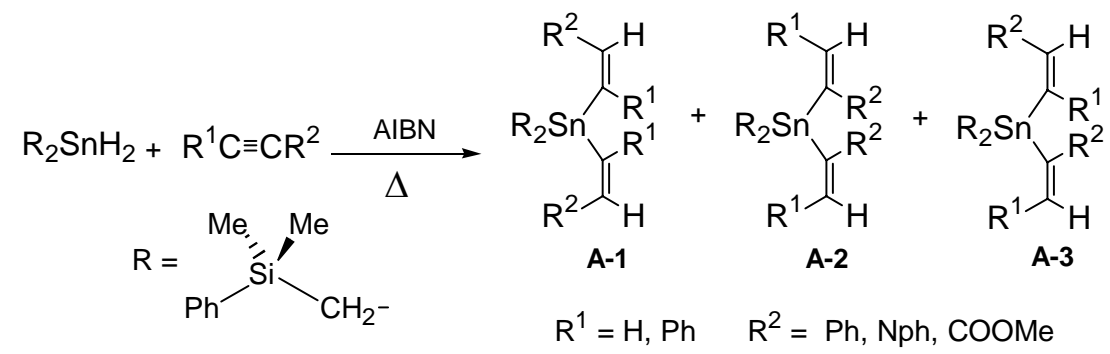

\section{Scheme 2}

Table 1. Tin tetrachloride alkylation under different conditions

\begin{tabular}{cccccc}
\hline \multirow{2}{*}{ Entry } & $3 / \mathrm{SnCl}_{4}$ ratio & Reaction Conditions & \multicolumn{2}{c}{ Yield } & \multicolumn{2}{c}{ Product Relationships (\%) } \\
\cline { 5 - 6 } & & $(\%)$ & $\mathrm{R}_{2} \mathrm{SnCl}_{2}$ & $\mathrm{R}_{3} \mathrm{SnCl}$ \\
\hline 1 & 2.1 & $(1) \mathrm{rt} ;(2) \mathrm{refx} 3 \mathrm{~h} ;(3) \mathrm{rt} 15 \mathrm{~h}$ & 78 & 51 & 49 \\
2 & 1.7 & $(1) \mathrm{rt} ;(2) \mathrm{refx} 3 \mathrm{~h} ;(3) \mathrm{rt} 15 \mathrm{~h}$ & 80 & 54 & 46 \\
3 & 2.1 & $(1) \mathrm{rt} ;(2) \mathrm{rt} 15 \mathrm{~h}$ & 76 & 62 & 38 \\
4 & 2.0 & $(1) \mathrm{rt} ;(2) \mathrm{rt} 48 \mathrm{~h}$ & 82 & 55 & 45 \\
5 & 2.0 & $(1) 0^{\circ} \mathrm{C} ;(2) \mathrm{rt} 2 \mathrm{~h}$ & 79 & 72 & 28 \\
6 & 1.6 & $(1) 0^{\circ} \mathrm{C} ;(2) \mathrm{refx} 1 \mathrm{~h}$ & 78 & 70 & 30 \\
7 & 1.5 & $(1) 0^{\circ} \mathrm{C} ;(2) \mathrm{rt} 2 \mathrm{~h}$ & 80 & 80 & 20 \\
\hline
\end{tabular}

${ }^{a}$ All the reactions were carried out by adding the Grignard reagent (GR) in diethyl ether onto a solution of $\mathrm{SnCl}_{4}$ in toluene; $\mathrm{rt}=$ room temperature; refx $=$ reflux. ${ }^{\mathrm{b}}$ From ${ }^{119} \mathrm{Sn}$ NMR spectra.

Table 2. Radical additions of bis[(phenyldimethylsilyl)methyl]tin dihydride (6) to alkynes ${ }^{\mathrm{a}}$

\begin{tabular}{|c|c|c|c|c|c|c|c|c|c|}
\hline $\begin{array}{c}\text { Compd } \\
\mathrm{N}^{\mathrm{o}} \\
\end{array}$ & Alkyne & $\begin{array}{c}\text { Time } \\
\text { (h) }\end{array}$ & $\mathrm{R}^{1}$ & $\mathrm{R}^{2}$ & $\begin{array}{l}\text { A-1 } \\
(\%) \\
\end{array}$ & $\begin{array}{l}\text { A-2 } \\
(\%) \\
\end{array}$ & $\begin{array}{l}\text { A-3 } \\
(\%) \\
\end{array}$ & $\begin{array}{c}\text { Yield }^{b} \\
(\%)\end{array}$ & $\begin{array}{c}{ }^{119} \mathrm{Sn} \\
(\mathrm{ppm})^{\mathrm{c}}\end{array}$ \\
\hline 7 & $\mathbf{a}$ & 4 & $\mathrm{H}$ & $\mathrm{Ph}$ & 100 & --- & --- & 86 & -91.6 \\
\hline 8 & b & 4 & $\mathrm{H}$ & 2-Nph & 100 & --- & --- & 85 & -91.0 \\
\hline $9 \& 10$ & C & 1 & $\mathrm{H}$ & COOMe & $50(9)$ & --- & $\begin{array}{c}30 \\
(\mathbf{1 0})\end{array}$ & $62^{d}$ & $\begin{array}{l}\text { 9: }-102.7 \\
\text { 10: }-86.9\end{array}$ \\
\hline 11 & d & 4 & $\mathrm{Ph}$ & $\mathrm{Ph}$ & 100 & --- & --- & 90 & -80.3 \\
\hline $12 \& 13$ & e & 1 & $\mathrm{Ph}$ & COOMe & $\begin{array}{c}80 \\
(\mathbf{1 2}) \\
\end{array}$ & $\begin{array}{c}20 \\
(\mathbf{1 3})\end{array}$ & --- & 78 & $\begin{array}{l}\text { 12: }-79.4 \\
\text { 13: }-94.3\end{array}$ \\
\hline
\end{tabular}

${ }^{a}$ The reactions were carried out under a nitrogen atmosphere; ratio alkyne/hydride $6=2.5$; AIBN 0.01 equiv; without solvent; at $75^{\circ} \mathrm{C}$. ${ }^{b}$ Yields of products isolated from chromatography. ${ }^{\mathrm{c}}$ In $\mathrm{CDCl}_{3}$; in ppm with respect to $\mathrm{Me}_{4} \mathrm{Sn}$. ${ }^{\mathrm{d}}$ The formation of some product of monoaddition was also detected. 
In Tables 3 and 4 are collected ${ }^{13} \mathrm{C}$ - and ${ }^{1} \mathrm{H}-\mathrm{NMR}$ data of the new organotins 7-13.

Table 3. ${ }^{13} \mathrm{C}$ NMR data of divinyltin adducts $\mathbf{7 - 1 3 ^ { \mathrm { a } }}$

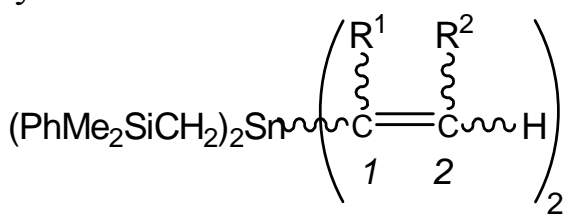

\begin{tabular}{|c|c|c|c|c|c|c|c|}
\hline $\begin{array}{c}\text { Adduct } \\
\mathrm{N}^{\circ}\end{array}$ & $\mathrm{R}^{1}$ & $\mathrm{R}^{2}$ & $\begin{array}{c}\mathrm{C}(1) \\
{\left[{ }^{1} \mathrm{~J}(\mathrm{Sn}, \mathrm{C})\right]}\end{array}$ & $\begin{array}{c}\mathrm{C}(2) \\
{\left[{ }^{2} \mathrm{~J}(\mathrm{Sn}, \mathrm{C})\right]}\end{array}$ & $\begin{array}{c}\mathrm{R}^{1 \mathrm{~b}} \\
{\left[{ }^{2} \mathrm{~J}(\mathrm{Sn}, \mathrm{C})\right]}\end{array}$ & $\begin{array}{c}\mathrm{R}^{2 \mathrm{~b}} \\
{\left[{ }^{3} \mathrm{~J}(\mathrm{Sn}, \mathrm{C})\right]}\end{array}$ & $\begin{array}{c}\text { Other } \\
\text { signals }\end{array}$ \\
\hline 7 & $\mathrm{H}$ & $\mathrm{Ph}$ & $\begin{array}{l}134.31 \\
(456.3)\end{array}$ & $146.70(\mathrm{nd})$ & --- & $\begin{array}{l}140.61 \\
(33.0)\end{array}$ & $\mathrm{c}$ \\
\hline 8 & $\mathrm{H}$ & 2-Nph & $\begin{array}{l}134.99 \\
(452.6)\end{array}$ & $146.64(\mathrm{nd})$ & --- & $\begin{array}{c}138.08 \\
(31.4)\end{array}$ & $d$ \\
\hline 9 & $\mathrm{H}$ & COOMe & $\begin{array}{l}160.47 \\
(416.1)\end{array}$ & $\begin{array}{l}133.31 \\
(11.4)\end{array}$ & --- & $\begin{array}{c}168.13 \\
(29.6)\end{array}$ & $\mathrm{e}$ \\
\hline \multirow[t]{2}{*}{10} & $\mathrm{H}$ & COOMe & $\begin{array}{l}157.03 \\
(433.4)\end{array}$ & $\begin{array}{c}134.56 \\
(10.5)\end{array}$ & --- & $\begin{array}{c}168.36 \\
(30.9)\end{array}$ & $\mathrm{f}$ \\
\hline & COOMe & $\mathrm{H}$ & $\begin{array}{l}148.65 \\
(390.6)\end{array}$ & $\begin{array}{l}141.51 \\
(23.3)\end{array}$ & $\begin{array}{c}170.63 \\
(43.9)\end{array}$ & --- & $\mathrm{f}$ \\
\hline 11 & $\mathrm{Ph}$ & $\mathrm{Ph}$ & $\begin{array}{l}149.97 \\
(420.4)\end{array}$ & $\begin{array}{l}144.16 \\
(24.0)\end{array}$ & $\begin{array}{c}139.54 \\
(24.3)\end{array}$ & $\begin{array}{c}146.78 \\
(35.1)\end{array}$ & $\mathrm{g}$ \\
\hline 12 & $\mathrm{Ph}$ & COOMe & $\begin{array}{l}140.53 \\
(447.8)\end{array}$ & $\begin{array}{c}154.05 \\
(12.1)\end{array}$ & $\begin{array}{c}137.92 \\
(22.3)\end{array}$ & $\begin{array}{l}171.11 \\
(42.0)\end{array}$ & $\mathrm{h}$ \\
\hline 13 & COOMe & $\mathrm{Ph}$ & $\begin{array}{l}140.04 \\
(422.1)\end{array}$ & $\begin{array}{c}153.93 \\
(30.2)\end{array}$ & $\begin{array}{c}170.84 \\
\text { (nd) }\end{array}$ & $\begin{array}{l}137.17 \\
(36.3)\end{array}$ & $\mathrm{i}$ \\
\hline
\end{tabular}

${ }^{\mathrm{a}}$ In $\mathrm{CDCl}_{3}$; chemical shifts, $\delta$, in ppm with respect to $\mathrm{TMS} ;{ }^{\mathrm{n}} \mathrm{J}(\mathrm{Sn}, \mathrm{C})$ and ${ }^{1} \mathrm{~J}(\mathrm{Si}, \mathrm{C})$ coupling constants, in $\mathrm{Hz}$ (in parentheses); nd = not determined; $\mathrm{Nph}=$ Naphthyl. ${ }^{\mathrm{b}}$ Chemical shifts of the carbons attached to $\mathrm{C}(1)$ and $\mathrm{C}(2){ }^{\mathrm{c}}-2.67$ (275.0) (49.8); 0.00 (53.6) (12.5); 127.50; 127.68; $128.21 ; 128.69 ; 133.41 ; 133.44 ; 141.36$ (20.8). ${ }^{\mathrm{d}}-2.46$ (277.5) (69.8); -0.00 (53.6) (13.0); $125.92 ; 126.20 ; 126.45 ; 127.66 ; 127.70 ; 127.73 ; 128.12 ; 128.65 ; 132.93 ; 133.33 ; 133.47$; $133.51 ; 141.24$ (22.8). $^{\mathrm{e}}-2.57$ (341.5) (51.5); 0.00 (52.0) (15.7); 51.51; 127.48; 128.47; 133.33; 141.57 (23.1). ${ }^{\mathrm{f}}-2.46$ (333.7) (48.8); 0.00 (51.7) (14.5); 0.18 (52.4) (16.5); 51.78; 51.96; 127.75; $128.79 ; 133.53 ; 139.60$ (15.6). ${ }^{\mathrm{g}}-0.73$ (268.3) (47.3); 0.00 (52.1) (12.3); 125.93; 127.24; 127.51; $127.80 ; 127.88 ; 128.08 ; 128.36 ; 128.52 ; 133.26 ; 141.31(24.3) .{ }^{\mathrm{h}} 0.00(52.4)(13.4) ; 1.38(307.8)$ (49.2); 52.06; 127.96; 128.53; 129.02; 129.25; $133.72 ; 141.66$ (24.6). ${ }^{\mathrm{i}}-1.81$ (324.3) (54.0); 0.00 (51.4) (14.2); 51.56; 127.14; 127.75; 128.07; 128.49; 133.00; 141.30 (20.1). 
The stereochemistry assigned to the new compounds 7-13 follows from the large ${ }^{3} \mathrm{~J}(\mathrm{Sn}, \mathrm{H})$ coupling constants, between 109 and $165 \mathrm{~Hz}$ (Table 4), that indicate the existence of trans $\mathrm{H}$ $\mathrm{C}=\mathrm{C}-\mathrm{Sn}$ linkages in these compounds.

Table 4. ${ }^{1} \mathrm{H}$ NMR data of divinyltin adducts 7-13

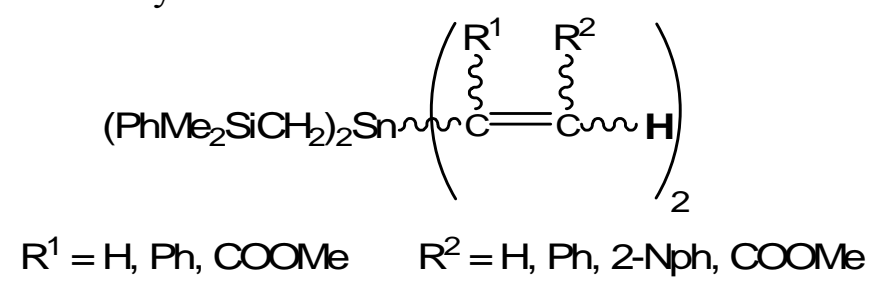

\begin{tabular}{|c|c|}
\hline Adduct $\mathrm{N}^{\circ}$ & Chemical shifts $(\delta, \text { in ppm })^{a}$ \\
\hline 7 & $\begin{array}{c}0.00\left(\mathrm{SiCH}_{2} \mathrm{Sn}\right)\left[\mathrm{s}, 4 \mathrm{H},{ }^{2} \mathrm{~J}(\mathrm{Sn}, \mathrm{H}) 71.2\right] ; 0.25\left(\mathrm{CH}_{3}\right)(\mathrm{s}, 12 \mathrm{H}) ; 6.12\left(\mathrm{R}^{1}=\mathrm{H}\right)[\mathrm{d}, 2 \mathrm{H}, \\
\left.{ }^{3} \mathrm{~J}(\mathrm{H}, \mathrm{H}) 13.5 ;{ }^{2} \mathrm{~J}(\mathrm{Sn}, \mathrm{H}) 72.0\right] ; 7.27-7.48\left(\mathrm{Ph} \& \mathrm{R}^{2}=\mathrm{Ph}\right)(\mathrm{m}, 20 \mathrm{H}) ; 7.53(\mathbf{H})[\mathrm{d}, 2 \mathrm{H}, \\
\left.{ }^{3} \mathrm{~J}(\mathrm{H}, \mathrm{H}) 13.5 ;{ }^{3} \mathrm{~J}(\mathrm{Sn}, \mathrm{H}) 165.6\right] .\end{array}$ \\
\hline 8 & $\begin{array}{c}-0.20\left(\mathrm{SiCH}_{2} \mathrm{Sn}\right)\left[\mathrm{s}, 4 \mathrm{H},{ }^{2} \mathrm{~J}(\mathrm{Sn}, \mathrm{H}) 75.8\right] ;-0.00\left(\mathrm{CH}_{3}\right)(\mathrm{s}, 12 \mathrm{H}) ; 6.02\left(\mathrm{R}^{1}=\mathrm{H}\right)[\mathrm{d}, \\
\left.2 \mathrm{H},{ }^{3} \mathrm{~J}(\mathrm{H}, \mathrm{H}) 12.7 ;{ }^{2} \mathrm{~J}(\mathrm{Sn}, \mathrm{H}) 72.5\right] ; 7.03-7.71\left(\mathrm{Ph} \& \mathrm{R}^{2}=2-\mathrm{Nph}\right)(\mathrm{m}, 24 \mathrm{H}) ; 7.53(\mathbf{H}) \\
{\left[\mathrm{d}, 2 \mathrm{H},{ }^{3} \mathrm{~J}(\mathrm{H}, \mathrm{H}) 12.7 ;{ }^{3} \mathrm{~J}(\mathrm{Sn}, \mathrm{H}) 163.9\right] .}\end{array}$ \\
\hline 9 & $\begin{array}{c}0.00\left(\mathrm{CH}_{3}\right)(\mathrm{s}, 12 \mathrm{H}) ; 0.18\left(\mathrm{SiCH} \mathrm{Sn}_{2}\right)\left[\mathrm{s}, 4 \mathrm{H},{ }^{2} \mathrm{~J}(\mathrm{Sn}, \mathrm{H}) 86.3\right] ; 3.52\left(\mathrm{R}^{2}=\mathrm{COOMe}\right) \\
(\mathrm{s}, 6 \mathrm{H}) ; 6.39(\mathbf{H})\left[\mathrm{d}, 2 \mathrm{H},{ }^{3} \mathrm{~J}(\mathrm{H}, \mathrm{H}) 12.6 ;{ }^{3} \mathrm{~J}(\mathrm{Sn}, \mathrm{H}) 136.5\right] ; 6.81\left(\left(\mathrm{R}^{1}=\mathrm{H}\right)[\mathrm{d}, 2 \mathrm{H}\right. \\
\left.{ }^{3} \mathrm{~J}(\mathrm{H}, \mathrm{H}) 12.6 ;{ }^{2} \mathrm{~J}(\mathrm{Sn}, \mathrm{H}) 67.9\right] ; 7.07-7.27(\mathrm{Ph})(\mathrm{m}, 10 \mathrm{H})\end{array}$ \\
\hline & $\begin{array}{l}0.00\left(\mathrm{CH}_{3}\right)(\mathrm{s}, 6 \mathrm{H}) ; 0.01\left(\mathrm{CH}_{3}\right)(\mathrm{s}, 6 \mathrm{H}) ; 0.14\left(\mathrm{SiCH}_{2} \mathrm{Sn}\right)\left[\mathrm{s}, 2 \mathrm{H},{ }^{2} \mathrm{~J}(\mathrm{Sn}, \mathrm{H}) 84.7\right] \\
0.16\left(\mathrm{SiCH}_{2} \mathrm{Sn}\right)\left[\mathrm{s}, 2 \mathrm{H},{ }^{2} \mathrm{~J}(\mathrm{Sn}, \mathrm{H}) 85.9\right] ; 3.48\left(\mathrm{R}^{1}=\mathrm{COOMe}\right)(\mathrm{s}, 3 \mathrm{H}) ; 3.50\left(\mathrm{R}^{2}=\right.\end{array}$ \\
\hline 10 & $\begin{array}{l}\mathrm{COOMe})(\mathrm{s}, 3 \mathrm{H}) ; 5.65\left(\mathrm{R}^{2}=\mathrm{H}\right)\left[\mathrm{d}, 1 \mathrm{H},{ }^{2} \mathrm{~J}(\mathrm{H}, \mathrm{H}) 2.5 ;{ }^{3} \mathrm{~J}(\mathrm{Sn}, \mathrm{H}) 61.2\right] ; 6.42(\mathbf{H})[\mathrm{d} \\
\left.1 \mathrm{H},{ }^{3} \mathrm{~J}(\mathrm{H}, \mathrm{H}) 12.1 ;{ }^{3} \mathrm{~J}(\mathrm{Sn}, \mathrm{H}) 145.6\right] ; 6.61(\mathbf{H})\left[\mathrm{d}, 1 \mathrm{H},{ }^{2} \mathrm{~J}(\mathrm{H}, \mathrm{H}) 2.5 ;{ }^{3} \mathrm{~J}(\mathrm{Sn}, \mathrm{H}) 120.4\right] \\
\quad 6.91\left(\mathrm{R}^{1}=\mathrm{H}\right)\left[\mathrm{d}, 1 \mathrm{H},{ }^{3} \mathrm{~J}(\mathrm{H}, \mathrm{H}) 12.1 ;{ }^{2} \mathrm{~J}(\mathrm{Sn}, \mathrm{H}) 73.8\right] ; 7.08-7.26(\mathrm{Ph})(\mathrm{m}, 10 \mathrm{H})\end{array}$ \\
\hline 11 & $\begin{array}{c}-0.28\left(\mathrm{SiCH}_{2} \mathrm{Sn}\right)\left[\mathrm{s}, 4 \mathrm{H},{ }^{2} \mathrm{~J}(\mathrm{Sn}, \mathrm{H}) 76.6\right] ; 0.00\left(\mathrm{CH}_{3}\right)(\mathrm{s}, 12 \mathrm{H}) ; 6.85-7.22\left(\mathbf{H}, \mathrm{Ph}, \mathrm{R}^{1}\right. \\
\left.=\mathrm{R}^{2}=\mathrm{Ph}\right)(\mathrm{m}, 32 \mathrm{H}) .\end{array}$ \\
\hline 12 & $\begin{array}{c}-0.06\left(\mathrm{SiCH}_{2} \mathrm{Sn}\right)\left[\mathrm{s}, 4 \mathrm{H},{ }^{2} \mathrm{~J}(\mathrm{Sn}, \mathrm{H}) 82.2\right] ; 0.00\left(\mathrm{CH}_{3}\right)(\mathrm{s}, 12 \mathrm{H}) ; 3.48\left(\mathrm{R}^{2}=\mathrm{COOMe}\right) \\
(\mathrm{s}, 6 \mathrm{H}) ;\left(\mathrm{Ph} \& \mathrm{R}^{1}=\mathrm{Ph}\right) 6.94-7.20(\mathrm{~m}, 20 \mathrm{H}) ; 8.00(\mathrm{H})\left[\mathrm{s}, 2 \mathrm{H},{ }^{3} \mathrm{~J}(\mathrm{Sn}, \mathrm{H}) 133.9\right] .\end{array}$ \\
\hline 13 & $\begin{array}{c}-0.07\left(\mathrm{SiCH}_{2} \mathrm{Sn}\right)\left[\mathrm{s}, 4 \mathrm{H},{ }^{2} \mathrm{~J}(\mathrm{Sn}, \mathrm{H}) 75.0\right] ; 0.00\left(\mathrm{CH}_{3}\right)(\mathrm{s}, 12 \mathrm{H}) ; 3.43\left(\mathrm{R}^{1}=\mathrm{COOMe}\right) \\
(\mathrm{s}, 6 \mathrm{H}) ; 7.05-7.32\left(\mathrm{Ph} \& \mathrm{R}^{2}=\mathrm{Ph}\right)(\mathrm{m}, 20 \mathrm{H}) ; 8.21(\mathrm{H})\left[\mathrm{s}, 2 \mathrm{H},{ }^{3} \mathrm{~J}(\mathrm{Sn}, \mathrm{H}) 109.4\right]\end{array}$ \\
\hline
\end{tabular}

${ }^{a}$ In $\mathrm{CDCl}_{3}$; chemical shifts, $\delta$, in ppm with respect to $\mathrm{TMS} ;{ }^{\mathrm{n}} \mathrm{J}(\mathrm{Sn}, \mathrm{H})$ and ${ }^{\mathrm{n}} \mathrm{J}(\mathrm{H}, \mathrm{H})$ coupling constants, in $\mathrm{Hz}$ (in parentheses).

Table 2 shows that the addition of hydride 6 to phenylethyne, naphthylethyne, methyl propiolate, diphenylethyne, and methyl 3-phenylpropiolate leads exclusively to the Zvinylstannanes resulting from an anti attack, typical of radical hydrostannations. ${ }^{2 f, 3,4}$

A remarkable fact is the formation of the $Z$-adducts as sole products in the additions of hydride 6 to phenylethyne, naphtylethyne, and diphenylethyne. In previous studies, we have 
shown that the addition of trineophyl- and tris[(phenyldimethylsilyl)methyl]tin hydrides to phenylethyne and diphenylethyne ${ }^{2 f, 3}$ leads to the E-adducts as the sole products. We explained the formation of the E-adducts by considering that the isomerization of the initially formed kinetic Z-products by further addition/elimination of the stannyl radical would favor, under the reaction conditions, the formation of the thermodynamically more stable E-vinylstannanes. The exclusive formation of the $Z$-adducts in the case of the addition of hydride 6 could be explained by taking into account that this organotin dihydride might be more reactive than the bulky trineophyl- and tris[(phenyldimethylsilyl)methyl]tin hydrides. Therefore, it should be capable of effecting a much faster hydrogen transfer to the intermediate alkyl radical during the second step of the radical propagation chain leading straight to the products.

Although in most cases symmetrical, adducts were obtained, i.e., both vinyl ligands with the same regiochemistry, an interesting fact is that in one of the five hydrostannations carried out with dihydride 6 we obtained as a minor product a mixed adduct, i.e., an adduct containing as vinyl ligands the two possible regioisomers: divinylstannane $\mathbf{1 0 .}$

The chemical reactivity of the new divinylstannanes is similar to that of other monovinyltriorganotins. Thus, the iododestannylation of adducts $\mathbf{7}$ and $\mathbf{1 1}$ leads to the corresponding iodovinyl compounds 14 and 15 in very high yields and with complete retention of the $Z$ configuration, as shown in Scheme 3.

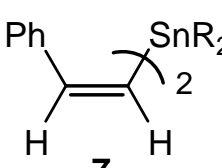

7

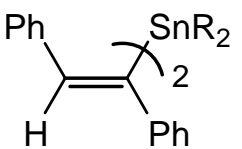

11

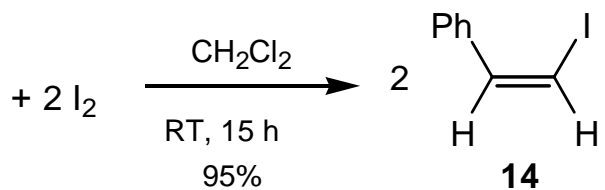

14

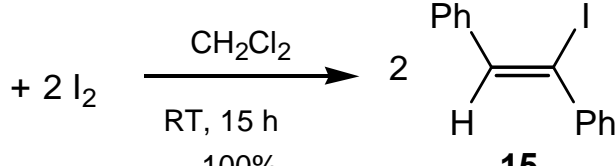

$100 \%$

15

$$
\mathrm{R}=\mathrm{CH}_{2} \mathrm{SiMe}_{2} \mathrm{Ph}
$$

\section{Scheme 3}

\section{Conclusions}

Our results demonstrate that by an adequate selection of the experimental parameters it is possible to obtain pure bis[(phenyldimethylsilyl)methyl]tin dichloride (5) in 55\% yield from the alkylation of tin tetrachloride with (phenyldimethylsilyl)methylmagnesium chloride (3). The reduction of 5 with lithium aluminum hydride leads to bis[(phenyldimethylsilyl)methyl]tin dihydride (6) with $85 \%$ yield. The hydrostannation under radical conditions of internal and terminal alkynes with $\mathbf{6}$ takes place stereoselectively leading to the products corresponding to an 
anti addition of the hydride to the carbon-carbon triple bond. The chemical reactivity of the new divinylstannanes is similar to that of other monovinyltriorganotins.

\section{Experimental Section}

General Procedures. NMR spectra were obtained in a Bruker ARX 300 instrument. Infrared spectra were recorded with a Nicolet Nexus FT spectrometer. Mass spectra were obtained using a Finnigan MAT Model 8230 at Dortmund University (Germany). Microanalyses were performed at Dortmund University. The melting points were determined in a Kofler hot stage and are uncorrected. Dimethyl(chloromethyl)chlorosilane (1) was purchased and (chloromethyl)phenyldimethylsilane (2) was obtained following known procedures. ${ }^{5}$ All the solvents and reagents used were analytical reagent grade.

\section{Synthesis of bis[(phenyldimethylsilyl)methyl]tin dichloride (5)}

To magnesium turnings $(1.12 \mathrm{~g}, 0.046 \mathrm{~mol})$ in dry diethylether $(10 \mathrm{ml})$ under stirring, was added slowly and dropwise a solution of (chloromethyl)phenyldimethylsilane (2) (7.78 g, $0.042 \mathrm{~mol}$ ) in diethyl ether $(30 \mathrm{ml})$. The preparation was carried out under an atmosphere of nitrogen. The reaction was exothermic and after the addition was completed the mixture was refluxed during 1 $\mathrm{h}$. Then the reaction mixture was stirred for $15 \mathrm{~h}$ at room temperature. The solution of the Grignard reagent 3 thus obtained had a $1.04 \mathrm{M}$ concentration.

To a solution of $\mathrm{SnCl}_{4}(3.3 \mathrm{ml}, 7.29 \mathrm{~g}, 0.028 \mathrm{~mol})$ in dry toluene $(66 \mathrm{ml})$ at $0^{\circ} \mathrm{C}$ under nitrogen, was added slowly and dropwise with stirring a solution of the Grignard reagent 3 in diethyl ether $(0.042 \mathrm{~mol}, 40 \mathrm{ml}$ of $1.04 \mathrm{M}$ solution). The mixture was stirred for $2 \mathrm{~h}$ at room temperature. After cooling at $0^{\circ} \mathrm{C}$, the reaction mixture was decomposed with a saturated solution of $\mathrm{NH}_{4} \mathrm{Cl}$ ( $\mathrm{ca} 50 \mathrm{ml}$ ). The organic layer was separated and the aqueous layer was extracted three times with diethyl ether ( $c a 30 \mathrm{ml}$ each). The combined organic extracts were dried over anhydrous $\mathrm{MgSO}_{4}$ and the solvent was removed under reduced pressure. The ${ }^{119} \mathrm{Sn}$ NMR of the resulting solid $(11.45 \mathrm{~g})$ showed it to consists of a mixture of bis[(phenyldimethylsilyl)methyl]tin dichloride (5) and tris[(phenyldimethylsilyl)methyl]tin chloride (4) and in a ratio 5/4 = 4:1 (11.45 g, $80 \%$ yield of organotin compounds based upon $\mathrm{SnCl}_{4}$ used). Repeated recrystallizations of the resulting mixture from n-heptane afforded 5 as a white crystalline solid (4.81 g, $0.010 \mathrm{~mol}, 55 \%)$. Mp: $75-76^{\circ} \mathrm{C}$. It should be noted that we have

previously reported the synthesis of 5 but in only a $21 \%$ yield. ${ }^{3}$ In reference 3 could be found the spectroscopic characteristics of 5 .

\section{Synthesis of bis[(phenyldimethylsilyl)methyl]tin dihydride (6)}

To a suspension of $\mathrm{LiAlH}_{4}(0.36 \mathrm{~g}, 9.4 \mathrm{mmol})$ in dry diethyl ether $(20 \mathrm{ml})$ under atmosphere of argon at room temperature, was added dropwise a solution of bis[(phenyldimethylsilyl) methyl]tin dichloride (5) (3.10 g, $6.3 \mathrm{mmol})$ in dry diethyl ether $(30 \mathrm{~mL})$. The mixture was heated under reflux for $5 \mathrm{~h}$ and a saturated solution of ammonium chloride was then added (ca 15 
$\mathrm{ml}$ ). The organic layer was separated, and the aqueous was extracted three times with diethyl ether. The combined organic extracts were dried over anhydrous $\mathrm{MgSO}_{4}$. Removal of the solvent under reduced pressure gave 6 as a liquid $(2.2 \mathrm{~g}, 5.4 \mathrm{mmol}, 85 \%)$. IR $\left(\mathrm{KBr}, \mathrm{cm}^{-1}\right)$ : $v_{\mathrm{Sn}-\mathrm{H}} 1833$. ${ }^{1} \mathrm{H}-\mathrm{NMR}\left(\mathrm{C}_{6} \mathrm{D}_{6}, \mathrm{Me}_{4} \mathrm{Si}\right) \delta \mathrm{ppm}: 0.00\left[\mathrm{t}, 4 \mathrm{H},{ }^{3} \mathrm{~J}(\mathrm{H}, \mathrm{H})=2.5 \mathrm{~Hz},{ }^{2} \mathrm{~J}(\mathrm{Sn}, \mathrm{H})=76.6 \mathrm{~Hz}\right] ; 0.34$ (s, 12 $\mathrm{H}) ; 4.79\left[\mathrm{q}, 2 \mathrm{H},{ }^{3} \mathrm{~J}(\mathrm{H}, \mathrm{H})=2.5 \mathrm{~Hz},{ }^{1} \mathrm{~J}(\mathrm{Sn}, \mathrm{H})=1804.7 \mathrm{~Hz}\right] ; 7.24-7.55(\mathrm{~m}, 10 \mathrm{H}) .{ }^{13} \mathrm{C}-\mathrm{NMR}$ $\left(\mathrm{C}_{6} \mathrm{D}_{6}, \mathrm{Me}_{4} \mathrm{Si}\right) \delta \mathrm{ppm}:-8.19\left[{ }^{1} \mathrm{~J}(\mathrm{Sn}, \mathrm{C})=270.8 \mathrm{~Hz},{ }^{1} \mathrm{~J}(\mathrm{Si}, \mathrm{C})=48.6 \mathrm{~Hz}\right] ; 0.00\left[{ }^{3} \mathrm{~J}(\mathrm{Sn}, \mathrm{C})=58.1\right.$ $\left.\mathrm{Hz},{ }^{1} \mathrm{~J}(\mathrm{Si}, \mathrm{C})=16.5 \mathrm{~Hz}\right] ; 128.70 ; 129.79 ; 134.29 ; 141.09\left[{ }^{3} \mathrm{~J}(\mathrm{Sn}, \mathrm{C})=18.1 \mathrm{~Hz}\right] .{ }^{119} \mathrm{Sn}-\mathrm{NMR}$ $\left(\mathrm{C}_{6} \mathrm{D}_{6}, \mathrm{Me}_{4} \mathrm{Sn}\right) \delta$ ppm: -207.9. Anal. Calcd. for $\mathrm{C}_{18} \mathrm{H}_{28} \mathrm{Si}_{2} \mathrm{Sn}$ : C, 51.56; H, 6.73. Found: C, 51.80; $\mathrm{H}, 6.80$.

Addition of bis[(phenyldimethylsilyl)methyl]tin dihydride (6) to substituted alkynes under radical conditions. Typical Procedure

A mixture of phenylacetylene $(0.12 \mathrm{~g}, 1.19 \mathrm{mmol})$, dihydride $6(0.20 \mathrm{~g}, 0.48 \mathrm{mmol})$, and AIBN as a catalyst, was heated under argon at $75{ }^{\circ} \mathrm{C}$ during $4 \mathrm{~h}$ (this optimal time of reaction and temperature was indicated by earlier experiments in which the reaction was monitored by taking samples at intervals and observing the disappearance of the $\mathrm{Sn}-\mathrm{H}$ absorption by IR). Column chromatography (silica gel 60) of the crude product afforded compound 7 ( $0.26 \mathrm{~g}, 0.41 \mathrm{mmol}, 86$ $\%$ ) in the fraction eluted with hexane- diethyl ether (99:1).

Bis[(phenyldimethylsilyl)methyl]di[(Z)-styryl]stannane (7). MS ( $\mathrm{m} / \mathrm{z}$, rel. int.): 520 (8\%, [M$\left.\mathrm{C}_{8} \mathrm{H}_{7}\right]^{+}$, Sn-pattern); 474 (100\%, [M- $\left.\left(\mathrm{CH}_{2} \mathrm{Si}\left(\mathrm{CH}_{3}\right)_{2} \mathrm{Ph}\right)\right]^{+}$, Sn-pattern); 417 (7\%, [M-2( $\left.\left.\mathrm{C}_{8} \mathrm{H}_{7}\right)\right]^{+}$, Sn-pattern); $371 \quad\left(23 \%, \quad\left[\mathrm{M}-\left(\mathrm{C}_{8} \mathrm{H}_{7}\right)-\left(\mathrm{CH}_{2} \mathrm{Si}\left(\mathrm{CH}_{3}\right)_{2} \mathrm{Ph}\right)\right]^{+}, \quad\right.$ Sn-pattern); $269 \quad(21 \%$, $\left[\mathrm{SnCH}_{2} \mathrm{Si}\left(\mathrm{CH}_{3}\right)_{2} \mathrm{Ph}\right]^{+}$, Sn-pattern $) ; 223\left(12 \%,\left[\mathrm{M}-\left(\mathrm{C}_{8} \mathrm{H}_{7}\right)-2\left(\mathrm{CH}_{2} \mathrm{Si}\left(\mathrm{CH}_{3}\right)_{2} \mathrm{Ph}\right)\right]^{+}, \mathrm{Sn}-\right.$ pattern $) ; 135$ $\left(27 \%,\left[\mathrm{Si}\left(\mathrm{CH}_{3}\right)_{2} \mathrm{Ph}\right]^{+}\right) ; 120\left(13 \%,[\mathrm{Sn}]^{+}, \mathrm{Sn}-\right.$ pattern $) ; 103\left(6 \%,\left[\mathrm{C}_{8} \mathrm{H}_{7}\right]^{+}\right)$. Anal. Calcd. for $\mathrm{C}_{34} \mathrm{H}_{40} \mathrm{Si}_{2} \mathrm{Sn}$ : C, 65.49; H, 6.46. Found: C, 65.70; H, 6.60.

Bis[(phenyldimethylsilyl)methyl]di[(Z)-(2-naphthalen-2-yl)vinyl]stannane (8). $\mathrm{MS}(\mathrm{m} / \mathrm{z}$, rel. int. $) \quad 574 \quad\left(100 \%, \quad\left[\mathrm{M}-\left(\mathrm{CH}_{2} \mathrm{Si}\left(\mathrm{CH}_{3}\right)_{2} \mathrm{Ph}\right)\right]^{+}, \quad\right.$ Sn-pattern $) ; \quad 420 \quad\left(88 \%, \quad\left[\mathrm{M}-\left(\mathrm{C}_{12} \mathrm{H}_{9}\right)-\right.\right.$ $\left.\left(\mathrm{CH}_{2} \mathrm{Si}\left(\mathrm{CH}_{3}\right)_{2} \mathrm{Ph}\right)\right]^{+}$, Sn-pattern); 306 (11\%, [M-2(C $\left.\left.\mathrm{C}_{12} \mathrm{H}_{9}\right)\right]^{+}$, Sn-pattern); $273\left(20 \%,\left[\mathrm{SnC}_{12} \mathrm{H}_{9}\right]^{+}\right.$, Sn-pattern); 269 (49\%, [SnCH $\left.\mathrm{Si}_{2}\left(\mathrm{CH}_{3}\right)_{2} \mathrm{Ph}\right]^{+}, \mathrm{Sn}$-pattern); $153\left(34 \%,\left[\mathrm{C}_{12} \mathrm{H}_{9}\right]^{+}\right) ; 135(40 \%$, $\left[\mathrm{Si}\left(\mathrm{CH}_{3}\right)_{2} \mathrm{Ph}\right]^{+} ; 120\left(17 \%,[\mathrm{Sn}]^{+}\right.$, Sn-pattern). Anal. Calcd. for $\mathrm{C}_{42} \mathrm{H}_{44} \mathrm{Si}_{2} \mathrm{Sn}: \mathrm{C}, 69.70 ; \mathrm{H}, 6.13$. Found: C, 69.80; H, 6.20.

Bis[(phenyldimethylsilyl)methyl]di[(Z)-methyl 3-acrylate]stannane (9). MS ( $\mathrm{m} / \mathrm{z}$, rel. int.): 503 (21\%, [M-C $\left.\mathrm{H}_{5} \mathrm{O}_{2}\right]^{+}$, Sn-pattern); 439 (100\%, [M- $\left.\left(\mathrm{CH}_{2} \mathrm{Si}\left(\mathrm{CH}_{3}\right)_{2} \mathrm{Ph}\right)\right]^{+}, \mathrm{Sn}$-pattern); 269 (7\%, $\left.\left[\mathrm{SnCH}_{2} \mathrm{Si}\left(\mathrm{CH}_{3}\right)_{2} \mathrm{Ph}\right)\right]^{+}, \quad \mathrm{Sn}$-pattern); $205 \quad\left(15 \%, \quad\left[\mathrm{SnC}_{4} \mathrm{H}_{5} \mathrm{O}_{2}\right]^{+}, \quad \mathrm{Sn}\right.$-pattern); $149 \quad$ (5\%, $\left.\left.\left[\mathrm{CH}_{2} \mathrm{Si}\left(\mathrm{CH}_{3}\right)_{2} \mathrm{Ph}\right]^{+}\right) ; 135\left(20 \%,\left[\mathrm{Si}\left(\mathrm{CH}_{3}\right)_{2} \mathrm{Ph}\right]^{+}\right) ; 120(9 \% \text {, [Sn] }]^{+}, \mathrm{Sn}-\mathrm{pattern}\right) ; 85\left(8 \%,\left[\mathrm{C}_{4} \mathrm{H}_{5} \mathrm{O}_{2}\right]^{+}\right)$. Anal. Calcd. for $\mathrm{C}_{26} \mathrm{H}_{36} \mathrm{O}_{4} \mathrm{Si}_{2} \mathrm{Sn}$ : C, 53.16; H, 6.17. Found: C, 59.70; H, 7.00.

Bis[(phenyldimethylsilyl)methyl][(Z)-methyl 3-acrylate](methyl 2-acrylate)stannane (10). MS (m/z, rel. int.): 503 (22\%, [M-C $\left.\mathrm{H}_{5} \mathrm{O}_{2}\right]^{+}, \mathrm{Sn}-$ pattern); $439\left(100 \% \text {, [M- }\left(\mathrm{CH}_{2} \mathrm{Si}\left(\mathrm{CH}_{3}\right)_{2} \mathrm{Ph}\right)\right]^{+}$, Sn-pattern); 269 (10\%, [ $\left.\left.\mathrm{SnCH}_{2} \mathrm{Si}\left(\mathrm{CH}_{3}\right)_{2} \mathrm{Ph}\right)\right]^{+}, \mathrm{Sn}$-pattern); 205 (10\%, [ $\left.\mathrm{SnC}_{4} \mathrm{H}_{5} \mathrm{O}_{2}\right]^{+}$, Sn-pattern); $149\left(5 \%,\left[\mathrm{CH}_{2} \mathrm{Si}\left(\mathrm{CH}_{3}\right)_{2} \mathrm{Ph}\right]^{+}\right) ; 135\left(22 \%,\left[\mathrm{Si}\left(\mathrm{CH}_{3}\right)_{2} \mathrm{Ph}\right]^{+}\right) ; 120\left(11 \%,[\mathrm{Sn}]^{+}, \mathrm{Sn}-\right.$ pattern $) ; 85$ (3\%, $\left[\mathrm{C}_{4} \mathrm{H}_{5} \mathrm{O}_{2}\right]^{+}$). Anal. Calcd. for $\mathrm{C}_{26} \mathrm{H}_{36} \mathrm{O}_{4} \mathrm{Si}_{2} \mathrm{Sn}$ : C, 53.16; H, 6.17. Found: C, 59.80; H, 7.10. 
Bis[(phenyldimethylsilyl)methyl]di[(Z)-1,2-diphenylvinyl]stannane (11). MS ( $\mathrm{m} / \mathrm{z}$, rel. int.): 627 (15\%, [M-( $\left.\left.\mathrm{CH}_{2} \mathrm{Si}\left(\mathrm{CH}_{3}\right)_{2} \mathrm{Ph}\right)\right]^{+}$, Sn-pattern); 597 (100\%, [M-C $\left.{ }_{14} \mathrm{H}_{11}\right]^{+}$, Sn-pattern); 419 (10\%, $\left[\mathrm{Sn}\left(\mathrm{CH}_{2} \mathrm{Si}\left(\mathrm{CH}_{3}\right)_{2} \mathrm{Ph}\right)_{2}\right]^{+}$, Sn-pattern); 269 (15\%, [ $\left.\mathrm{SnCH}_{2} \mathrm{Si}\left(\mathrm{CH}_{3}\right)_{2} \mathrm{Ph}\right]^{+}, \mathrm{Sn}-$ pattern); 179 (51\%, $\left.\left[\mathrm{C}_{14} \mathrm{H}_{11}\right]^{+}\right) ; 135\left(27 \%,\left[\mathrm{Si}\left(\mathrm{CH}_{3}\right)_{2} \mathrm{Ph}\right]^{+}\right) ; 120(6 \% \text {, [Sn] }]^{+}$, Sn-pattern). Anal. Calcd. for $\mathrm{C}_{46} \mathrm{H}_{48} \mathrm{Si}_{2} \mathrm{Sn}$ : C, 71.22; H, 6.23. Found: C, 70.90; H, 6.10.

Bis[(phenyldimethylsilyl)methyl]di[(Z)-(3-phenyl)methyl 3-acrylate]stannane (12). MS ( $\mathrm{m} / \mathrm{z}$, rel. int.): 591 (100\%, [M- $\left.\left(\mathrm{CH}_{2} \mathrm{Si}\left(\mathrm{CH}_{3}\right)_{2} \mathrm{Ph}\right)\right]^{+}$, Sn-pattern); 579 (14\%, [M-C $\left.{ }_{10} \mathrm{H}_{9} \mathrm{O}_{2}\right]^{+}, \mathrm{Sn}-$ pattern); $430\left(10 \%,\left[\mathrm{M}-\left(\mathrm{CH}_{2} \mathrm{Si}\left(\mathrm{CH}_{3}\right)_{2} \mathrm{Ph}\right)-\left(\mathrm{C}_{10} \mathrm{H}_{9} \mathrm{O}_{2}\right)\right]^{+}, \mathrm{Sn} \text {-pattern); } 281 \text { (5\%, [ } \mathrm{SnC}_{10} \mathrm{H}_{9} \mathrm{O}_{2}\right]^{+}, \mathrm{Sn}-$ pattern); $269\left(8 \%, \quad\left[\mathrm{SnCH}_{2} \mathrm{Si}\left(\mathrm{CH}_{3}\right)_{2} \mathrm{Ph}\right]^{+}\right.$, Sn-pattern); $149 \quad\left(10 \%, \quad\left[\mathrm{CH}_{2} \mathrm{Si}\left(\mathrm{CH}_{3}\right)_{2} \mathrm{Ph}\right]^{+}\right) ; 135 \quad(14 \%$, $\left.\left[\mathrm{Si}\left(\mathrm{CH}_{3}\right)_{2} \mathrm{Ph}\right]^{+}\right) ; 120\left(13 \%,[\mathrm{Sn}]^{+}\right.$, Sn-pattern); $91\left(8 \%,\left[\mathrm{C}_{7} \mathrm{H}_{7}\right]^{+}\right)$. Anal. Calcd. for $\mathrm{C}_{38} \mathrm{H}_{44} \mathrm{O}_{4} \mathrm{Si}_{2} \mathrm{Sn}$ : C, 61.71; H, 5.99. Found: C, 61.70; H, 5.80.

Bis[(phenyldimethylsilyl)methyl]di[(Z)-(3-phenyl)methyl 2-acrylate]stannane (13). MS ( $\mathrm{m} / \mathrm{z}$, rel. int.): 591 (100\%, [M-( $\left.\left.\mathrm{CH}_{2} \mathrm{Si}\left(\mathrm{CH}_{3}\right)_{2} \mathrm{Ph}\right)\right]^{+}$, Sn-pattern); $579\left(10 \% \text {, [M-C }{ }_{10} \mathrm{H}_{9} \mathrm{O}_{2}\right]^{+}$, Sn-pattern); $430\left(12 \% \text {, [M- }\left(\mathrm{CH}_{2} \mathrm{Si}\left(\mathrm{CH}_{3}\right)_{2} \mathrm{Ph}\right)-\left(\mathrm{C}_{10} \mathrm{H}_{9} \mathrm{O}_{2}\right)\right]^{+}, \mathrm{Sn}$-pattern $) ; 281$ (8\%, [ $\left.\mathrm{SnC}_{10} \mathrm{H}_{9} \mathrm{O}_{2}\right]^{+}$, Sn-pattern); $269\left(10 \%,\left[\mathrm{SnCH}_{2} \mathrm{Si}\left(\mathrm{CH}_{3}\right)_{2} \mathrm{Ph}\right]^{+}, \mathrm{Sn}-\right.$ pattern $) ; 149\left(10 \%,\left[\mathrm{CH}_{2} \mathrm{Si}\left(\mathrm{CH}_{3}\right)_{2} \mathrm{Ph}\right]^{+}\right) ; 135 \quad(12 \%$, $\left.\left[\mathrm{Si}\left(\mathrm{CH}_{3}\right)_{2} \mathrm{Ph}\right]^{+}\right) ; 120\left(9 \%,[\mathrm{Sn}]^{+}, \mathrm{Sn}-\right.$ pattern $) ; 91\left(11 \%,\left[\mathrm{C}_{7} \mathrm{H}_{7}\right]^{+}\right)$. Anal. Calcd. for $\mathrm{C}_{38} \mathrm{H}_{44} \mathrm{O}_{4} \mathrm{Si}_{2} \mathrm{Sn}$ : C, 61.71; H, 5.99. Found: C, 61.50; H, 5.90.

Iododestannylation reactions: synthesis of (Z)-1-iodo-2-phenylethene (14) and (Z)-1-iodo1,2-diphenylethene (15)

To a solution of compound $7(0.25 \mathrm{~g}, 0.40 \mathrm{mmol})$ in dry $\mathrm{CH}_{2} \mathrm{Cl}_{2}(4.5 \mathrm{ml})$ under argon was added iodine $(0.22 \mathrm{~g}, 0.88 \mathrm{mmol})$. The mixture was stirred at room temperature for $15 \mathrm{~h}$ with monitoring of the reaction by TLC. Column chromatography on silica gel 60 (relation 70:1) of the crude product gave the iodovinyl compound 14 in the fraction eluted with hexane $(0.17 \mathrm{~g}$, $0.76 \mathrm{mmol}, 95 \%)$. Similarly, iododestannylation of bis[(phenyldimethylsilyl)methyl $]$ di $[(Z)-1,2-$ diphenylvinyl]stannane (11) leads quantitatively to compound 15.

\section{Acknowledgments}

This work was supported by CONICET (Capital Federal, Argentina) and Universidad Nacional del Sur (Bahía Blanca, Argentina). We are thankful to Prof. T.N. Mitchell, Dortmund University (Germany) for his help in connection with the mass spectra and elemental analyses. A travel grant to one of us (JCP) from the Alexander von Humboldt Foundation (Germany) is also gratefully acknowledged.

\section{References}

1. (a) Pereyre, M.; Quintard, J.-P.; Rahm, A. Tin in Organic Synthesis, Butterworths: London, 1987. (b) Davies, A. Organotin Chemistry, VCH: Weinheim, 1997. (c) Mitchell, T. N. 
Organotin Reagents in Cross-Coupling, Chapter 4 In Metal-catalized Cross-coupling Reactions; Diederich, F.; Stang, P. J., Eds; Wiley-VCH: Weinheim, 2001. (d) Giese, B. Radicals in Organic Synthesis: Formation of Carbon-Carbon Bonds, Pergamon Press: Oxford, 1986. (e) Marshall, J. A. Organotin Chemistry, In Organometallics in Synthesis: A Manual, Schlosser, M., Ed.; Wiley: New York, 2002.

2. (a) Mata, E. G.; Mascaretti, O. A.; Zúñiga, A. E.; Chopa; A. B.; Podestá, J. C. Tetrahedron Lett. 1989; 30, 3905. (b) Podestá, J. C.; Giagante, N. N.; Zúñiga, A. E.; Danelo, G. O.; Mascaretti, O. A. J. Org. Chem. 1994, 62, 6458. (c) Podestá, J. C.; Chopa, A. B.; Giagante, N. N.; Zúñiga, A. E. J. Organomet. Chem. 1995, 494, 5. (d) Podestá, J. C.; Chopa, A. B.; Radivoy, G. E.; Vitale, C. A. J. Organomet. Chem. 1995, 494, 11. (e) Vitale, C. A.; Podestá, J.C. J. Chem. Soc., Perkin Trans. 1 1996, 2407. (f) Dodero, V. I.; Koll, L. C.; Mandolesi, S. D.; Podestá, J. C. J. Organomet. Chem. 2002, 650, 173.

3. Dodero, V. I.; Mitchell, T. N.; Podestá, J. C. Organometallics 2003, 22, 856.

4. Dodero, V. I.; Koll, L. C.; Faraoni, M. B.; Mitchell, T. N.; Podestá, J. C. J. Org. Chem. 2003, 68, 10087.

5. Carleer, R.; Anteunis, M. J. Org. Magn. Reson. 1980, 13, 253. 